

\title{
Synthesis of new sulfated disaccharides for the modulation of TLR4-dependent inflammation
}

Rachid Naïtaleb, Agnes Denys, Fabrice Allain, Jérôme Ausseil, Sylvestre

Toumieux, José Kovensky

\section{- To cite this version:}

Rachid Naïtaleb, Agnes Denys, Fabrice Allain, Jérôme Ausseil, Sylvestre Toumieux, et al.. Synthesis of new sulfated disaccharides for the modulation of TLR4-dependent inflammation. Organic \& Biomolecular Chemistry, 2021, Organic \& Biomolecular Chemistry, 1919 (19), pp.4346-4351. 10.1039/d1ob00692d . hal-03537186

\section{HAL Id: hal-03537186 \\ https://hal.univ-lille.fr/hal-03537186}

Submitted on 24 Jan 2022

HAL is a multi-disciplinary open access archive for the deposit and dissemination of scientific research documents, whether they are published or not. The documents may come from teaching and research institutions in France or abroad, or from public or private research centers.
L'archive ouverte pluridisciplinaire HAL, est destinée au dépôt et à la diffusion de documents scientifiques de niveau recherche, publiés ou non, émanant des établissements d'enseignement et de recherche français ou étrangers, des laboratoires publics ou privés. 


\section{ARTICLE}

\section{Synthesis of new sulfated disaccharides for the modulation of TLR4-dependent inflammation}

Rachid Naitaleb, ${ }^{a}$ Agnès Denys, ${ }^{b}$ Fabrice Allain, ${ }^{\mathrm{b}}$ Jérôme Ausseil, ${ }^{\mathrm{c}}$ Sylvestre Toumieux ${ }^{* a}$ and José Kovensky *a

Natural sulfated glycans are key players in inflammation through TLR4 activation, and therefore synthetic exogenous sulfated saccharides can be used to downregulate inflammation processes. We had designed and synthesized new sulfated compounds based on small and biocompatible carbohydrates able to cross the BBB. Suitable protected donor and acceptor, obtained from a unique precursor, have been stereoselectively glycosylated to give an orthogonally protected cellobiose disaccharide. Selective deprotection and sulfation allowed to synthesize four differentially sulfated disaccharides, which have been characterized by NMR, HRMS and MS/MS. Together with their partially protected precursors, the new compounds were tested on HEF-TLR4 cells. Our results show the potential of small oligosaccharides to modulate TLR4 activity, confirming the need of sulfation and the key role of the 6 -sulfate groups to trigger TLR4 signalization.

\section{Introduction}

Toll-like receptors (TLRs) are a type of pattern recognition receptors (PRR) that identify molecules shared by pathogens but distinguishable from host molecules collectively referred to as pathogen-associated molecular patterns (PAMPs). TLRs play a critical role by triggering the molecular activation cascade that regulates the innate immune response/inflammatory process. ${ }^{1,2,3}$ The upregulation of TLR with the development of TLR agonists could be useful for various tumor treatment, ${ }^{4}$ allergies, ${ }^{5}$ infectious disease (HBV, malaria). ${ }^{6}$ The downregulation with antagonists is implicated in pathologies such as sepsis, ${ }^{7}$ type $1 \& 2$ diabetes, ${ }^{8,9}$ or neuroinflammation. ${ }^{10}$

Among TLRs, TLR4 is a key cell surface receptor involved in innate and adaptive immune response. This receptor is activated through the exposure of the lipopolysaccharide (LPS), lipid A or lipooligosaccharides (LOS) and initiate the production of a number of inflammatory mediators, including IL-1 $\beta$, TNF- $\alpha$, and macrophage inflammatory protein 1 alpha (MIP1 $\alpha$ ) via TLR4-dependent activation through the MyD88 adaptor and the NF-kB pathway. ${ }^{11}$ It can be found on the surface of microglial cells in the central nervous system (CNS), brain or spinal cord. Interestingly, neuroinflammation is known to play a decisive role in neurological diseases such as neurodegeneration. ${ }^{10}$ Thus, targeting brain inflammation represents a potential clinical intervention strategy for such pathologies but the blood brain barrier (BBB) is one of the main hurdles to access the CNS. Some molecules able to modulate the TLR4 response, have been tested previously and are often too big and/or not specific enough. Nevertheless, some small molecule modulators, able to cross the BBB, have been reported to have antagonist activities. ${ }^{12,13,14,15,16}$

Sulfated glycans such as glycosaminoglycans on proteoglycans are key players in both molecular and cellular events of inflammation through TLR4 activation. For example, it has been shown that heparan sulfate is degraded in inflammation to become a potent TLR4 ligand, and that TLR4 can be activated by small soluble fragments of heparan sulfate. Therefore, exogenous sulfated glycans of various structures and origins can be used to interventionally 
downregulate inflammation processes. ${ }^{17,18,19}$ As example, disaccharides like Lipid A and analogs have proven to establish interaction with TLR4 and could be potent interesting modulators. ${ }^{20,21}$

Herein, we propose to modulate TLR4 activity to reduce neurodegeneration by the modulation of the neuroinflammation. We have designed and synthesized new sulfated saccharides acting as inflammation regulator in order to restrain the neuroinflammation. Those modulators are based on small and biocompatible carbohydrates and then, would be able to pass the BBB.

\section{Results and discussion}

The synthetic route is depicted in Scheme 1. Regioselective reductive opening of the benzylidene acetal of known phenyl 2,3-di-O-acetyl-4,6-O-benzylidene-1-thio- $\beta$-D-glucopyranoside $(\mathbf{1})^{22}$ was performed using trifluoroacetic acid (TFA) and triethylsilane (TES) to give the 6-O-benzyl derivative $\mathbf{2}$ in $94 \%$ yield. The 4-hydroxyl was temporarily protected as a 2,2,2-trichloroethoxycarbonyl (Troc), followed by the selective removal of the thiophenyl group of compound $\mathbf{3}$ in the presence of trichloroisocyanuric acid (TCCA) ${ }^{23}$ affording $\mathbf{4}$ in $80 \%$ yield. This method is cleaner than the traditional use of NBS to cleave the C-S linkage. Adding dichloromethane at the end of the reaction produces the precipitation of the isocyanuronic acid and makes the workup very simple.

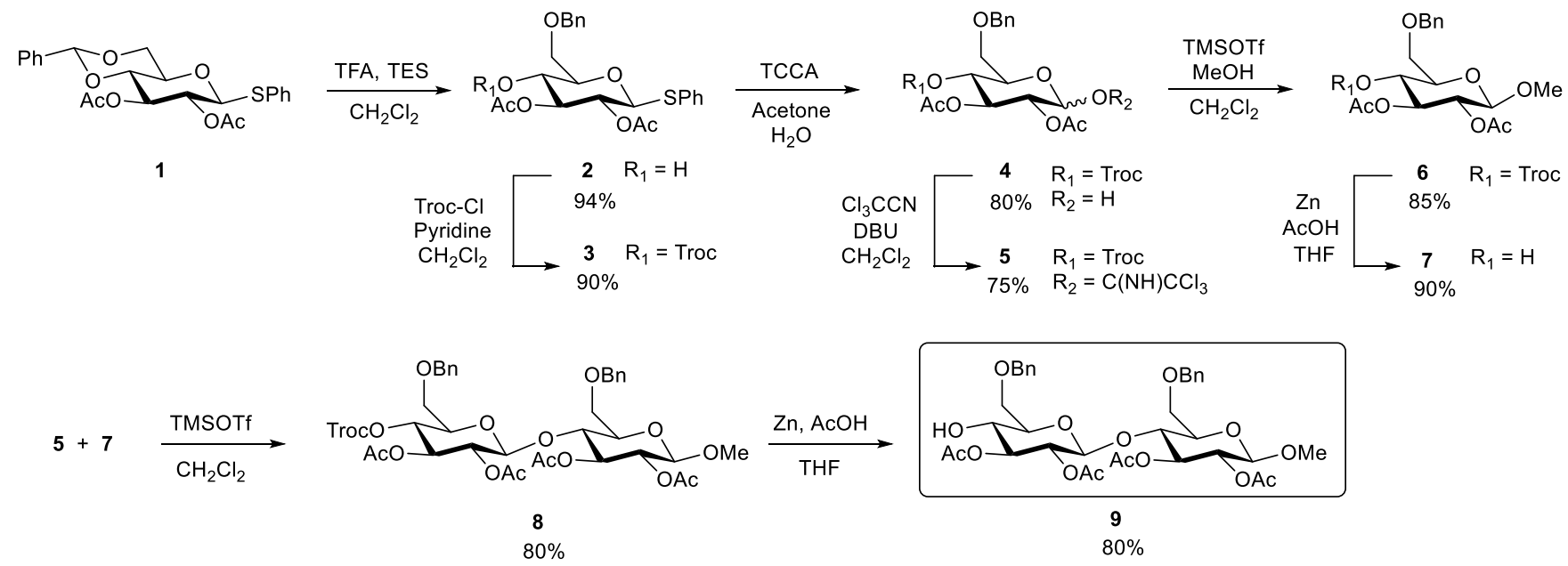

Scheme 1. Synthesis of orthogonally protected disaccharide 9.

Reaction with trichloroacetonitrile in the presence of DBU led to the trichloroacetimidate donor 5 (75\% yield). The ${ }^{1} \mathrm{H}$ NMR spectrum revealed its $\alpha$ configuration $(\delta 6.50, \mathrm{~d}, J=3.6 \mathrm{~Hz}, 1 \mathrm{H}, \mathrm{H}-1)$. The glycosyl acceptor was prepared from compound $\mathbf{5}$ in two steps. First, glycosylation with methanol was achieved using TMSOTf as promotor to give the methyl glucopyranoside 6 with total $\beta$ stereoselectivity shown by the $\mathrm{H}-1$ doublet at $\delta 4.39(\mathrm{~J}=7.9 \mathrm{~Hz})$ in the ${ }^{1} \mathrm{H}$ NMR spectrum, as expected in the presence of an acetate participating group at $\mathrm{C}-2$. Second, the Troc protecting group was selectively removed by activated $\mathrm{Zn} / \mathrm{AcOH}$ in THF. The acceptor $\mathbf{7}$ was obtained in $90 \%$ yield. ${ }^{24}$ 


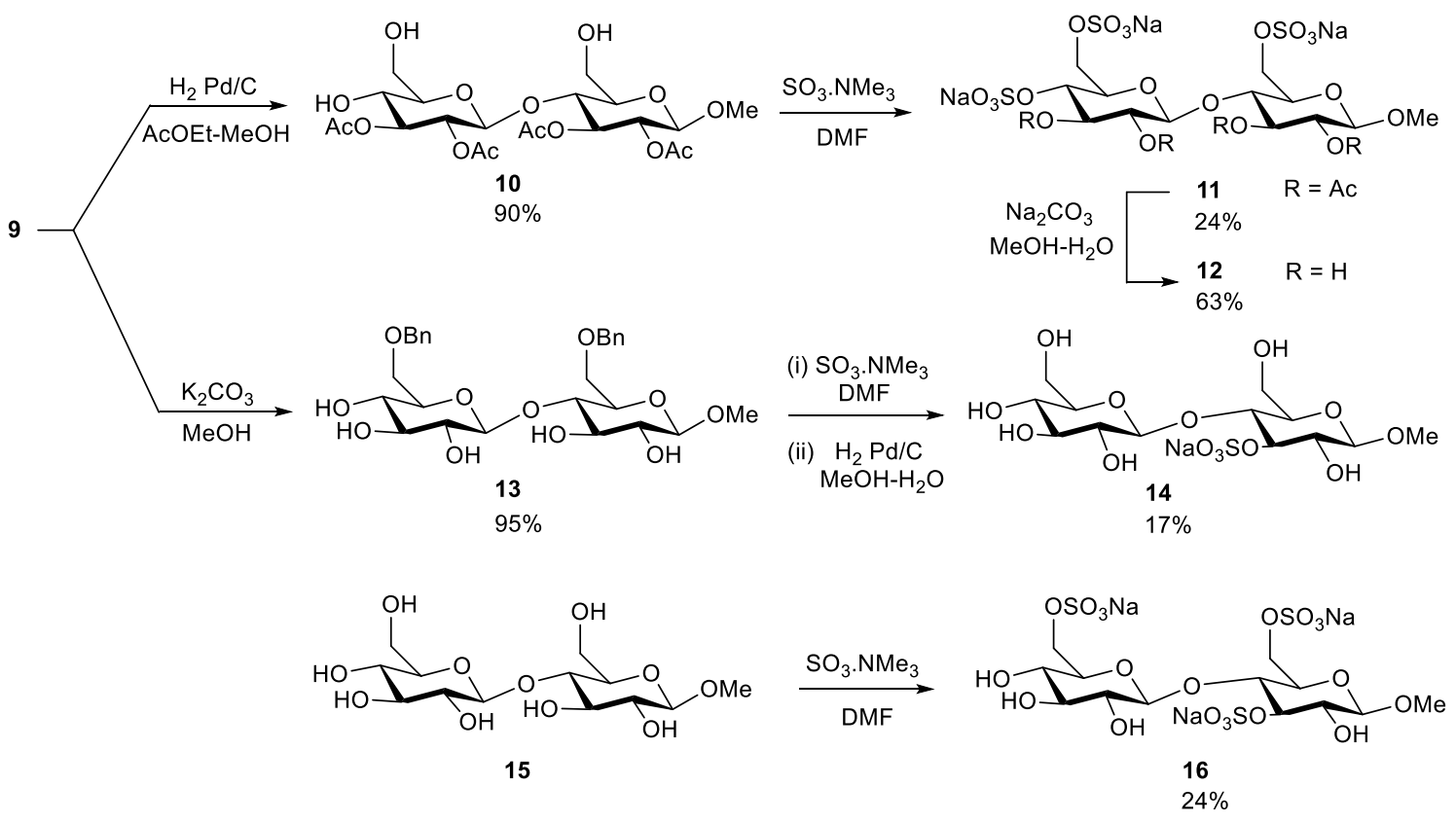

Scheme 2. Synthesis of diversely sulfated products.

Glycosylation between the donor 5 and acceptor $\mathbf{7}$ promoted by TMSOTf proceeded smoothly at room temperature affording the disaccharide 8 in $80 \%$ yield. In the ${ }^{1} \mathrm{H}$ NMR spectrum, the anomeric protons appeared at $4.42 \mathrm{ppm}(\mathrm{d}$, $J=8.0 \mathrm{~Hz}, \mathrm{H}-1)$ and $4.33 \mathrm{ppm}(\mathrm{d}, J=7.9 \mathrm{~Hz}, 1 \mathrm{H}, \mathrm{H}-1)$, whereas the ${ }^{13} \mathrm{C}$ NMR spectrum showed the signals of $\mathrm{C}-1^{\prime}$ and C-1 at $\delta 101.0$ and 100.0, respectively. Treatment of compound 8 in the same conditions used above to remove the Troc group gave the key disaccharide 9 in $80 \%$ yield.

The disaccharide 9 can be orthogonally deprotected in order to obtain regioselective sulfated products (Scheme 2). Catalytic hydrogenation over $10 \% \mathrm{Pd} / \mathrm{C}$ allowed to cleavage the benzyl groups, leading to the triol $\mathbf{1 0}$. Sulfation using $\mathrm{SO}_{3}$-trimethylamine complex ( 5 equiv./OH) afforded $\mathbf{1 1}$, which by deacetylation gave the compound $\mathbf{1 2}$. On the other hand, deacetylation of $\mathbf{9}$ afforded compound $\mathbf{1 3}$ which has five free hydroxyls. Sulfation of $\mathbf{1 3}$ as above followed by hydrogenolysis led to compound 14. For comparison, known methyl cellobioside $\mathbf{1 5}$ was also sulfated to give compound 16.

All the sulfation reactions proceeded well, but the extensive purifications had to be performed to completely eliminate the excess of sulfating agent on Sephadex LH-20, and the isolated yields were poor (24\%). Nevertheless, the sequence allowed us to obtain a family of differently sulfated disaccharides useful to analyze the structureactivity relationships.

We expected some regioselectivity of the sulfation reaction. However, the analysis of sulfated disaccharides was not straightforward, and a combination of NMR and MS analysis were necessary to determine the structure of compounds 11, 12, 14 and 16.

The simplest case was the sequence $\mathbf{1 0} \rightarrow \mathbf{1 1} \rightarrow \mathbf{1 2}$. HRMS (negative mode) of compound $\mathbf{1 1}$ showed unambiguously the presence of three sulfates, $\mathrm{m} / \mathrm{z} 807.0028[\mathrm{M}-3 \mathrm{H}+2 \mathrm{Na}]^{-}$. Thus, in our conditions, the sulfation of the primary 
positions was accompanied by the sulfation of the 4-position. In the ${ }^{13} \mathrm{C}$ NMR of compound 11, the resonances of the sulfated primary positions C- 6 and C- 6 ' appeared at $\delta 65.5$ and 66.5, a deshielding of about 7 ppm when compared to those of compound 10. The corresponding signal of C-4' shifted from $\delta 69.2$ to 73.9 upon sulfation.

The deacetylation step led to compound 12, and the presence of the three sulfate groups was confirmed on positions 6-, 4' - and 6'- by NMR. The HRMS at $\mathrm{m} / \mathrm{z} 638.9576$ fitted well with the trisulfated disaccharide structure. MS/MS of this ion showed main fragments at $\mathrm{m} / \mathrm{z} 519.00$ (corresponding to the loss of $\mathrm{NaSO}_{3}$ and water) and the peaks arising from cleavages at the interglycosidic linkage (Scheme 3). The peak at $\mathrm{m} / \mathrm{z} 342.94$ (C cleavage, loss of water) is consistent with a monosaccharide fragment carrying two sulfate groups, whereas the other sulfate is found in the reducing end fragment ( $Z$ cleavage, $\mathrm{m} / \mathrm{z} 273.03$ ).

Sulfation of compound $\mathbf{1 3}$ was performed in the same conditions used above. Unfortunately, different purifications by flash chromatography (reverse phase) of the sulfated product did not allow to obtain this intermediate in pure form, hydrogenolysis of the benzyl groups were accomplished and the deprotected sulfated molecule $\mathbf{1 4}$ was finally purified by Sephadex LH20. HRMS of compound $\mathbf{1 4}$ showed the presence of one sulfate group, as the molecular ion $\left[\mathrm{M}-\mathrm{H}^{-}\right.$appeared at $\mathrm{m} / \mathrm{z} 435.0860$. As the secondary hydroxyls are less reactive than the primary positions (blocked as benzyl ethers in compound 13), the sulfation did not lead to an oversulfated product. From the five available positions, the question is to determine the exact location of the sulfate group in compound $\mathbf{1 4}$.

MS/MS of the molecular ion gave limited information. The main fragments observed were at $\mathrm{m} / \mathrm{z} 273.00$ ( $\mathrm{Y}$ interglycosidic cleavage), $\mathrm{m} / \mathrm{z} 254.99$ and $\mathrm{m} / \mathrm{z} 240.98$ (loss of water and methanol, respectively, from the precedent ion), consistent with the location of the sulfate group at the reducing end.

NMR spectra of compound $\mathbf{1 4}$ were assigned by comparison with those of methyl cellobioside $\mathbf{1 5}$. The HSQC NMR spectrum of compound 14 showed a downfield shifted triplet at $\delta 4.35$ (that can be assigned to $\mathrm{H}-3$ ) that correlates with a peak at $\delta 84.0$ (thus assigned to $C$-3). In addition, the little difference between chemical shifts of $C-1$ between the non-sulfated and the sulfated product indicated that the sulfate group cannot be at $\mathrm{C}-2$. Therefore, the structure of compound $\mathbf{1 4}$ corresponds to a 3-sulfate methyl cellobioside.

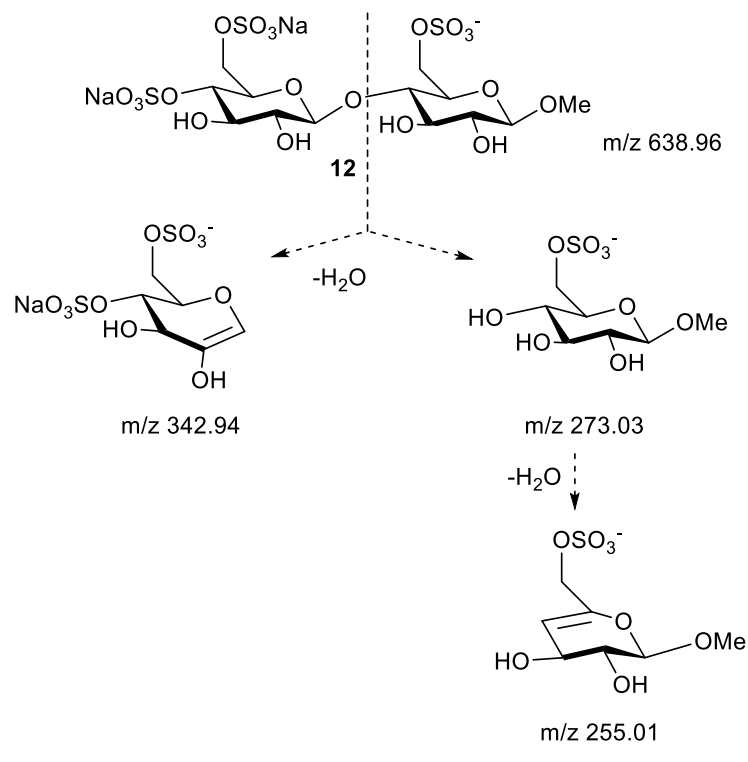

Scheme 3. MS/MS analysis of molecular ion of compound 12. 


\section{ARTICLE}
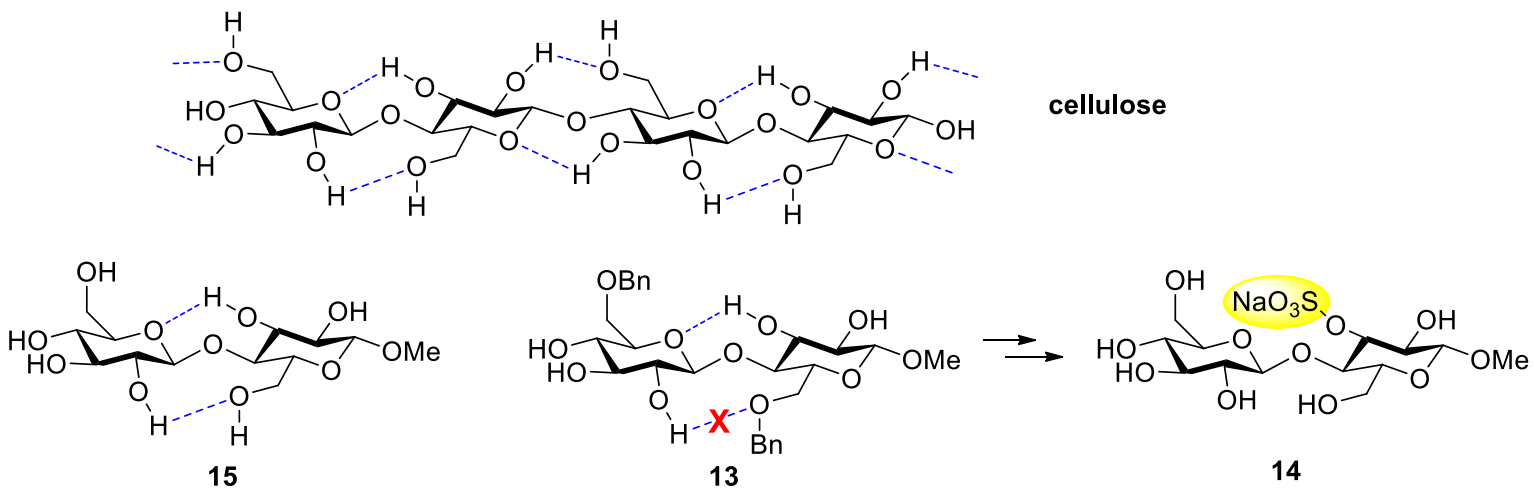

Scheme 4. Conformation of cellulose and methyl cellobiosides and regioselectivity of the sulfation of compound 13. 
This regioselectivity for the $0-3$ can be explained assuming a conformation of cellobiose similar to those found in cellulose (Scheme 4). In methyl cellobioside 15, the reactivity would be enhanced for both $0-3$ (linked through hydrogen bond to the sugar $0-5$ ) and $0-2^{\prime}$ (linked through hydrogen bond to the $0-6$ ). However, in compound 13, the 6-oxygen is blocked with a benzyl group, therefore the $0-2^{\prime}$ is no longer activated for substitution and sulfation takes place on position -3.

Finally, methyl cellobioside $\mathbf{1 5}$ was directly sulfated and the major compound $\mathbf{1 6}$ was purified and analyzed. The HRMS showed the molecular ion at $\mathrm{m} / \mathrm{z} 638.9604$, indicating a trisulfated disaccharide. The preferentially substitution is expected to occur at 6 - and $6^{\prime}$-positions. In the ${ }^{13} \mathrm{C}$ NMR spectrum of 16 a shift was observed for the resonances corresponding to C- 6 and C- $6^{\prime}$ when compared to those in the spectrum of 15 , from $\delta 61.4$ and 61.9 to $\delta 68.9$ and 69.3 , respectively, confirming the assignment. NMR spectra also showed that this trisulfated disaccharide 16 is different of that compound 12, which is also sulfated at C- 6 and C- $6^{\prime}$ but possess an additional sulfate at C-4'. MS/MS of the molecular ion showed a diagnostic fragment at $\mathrm{m} / \mathrm{z} 374.97$, indicating the presence of the remaining sulfate on the reducing unit (Scheme 5). From the two possible hydroxyls, NMR spectra of compound 16 are consistent with the presence of the additional sulfate group at position C-3.

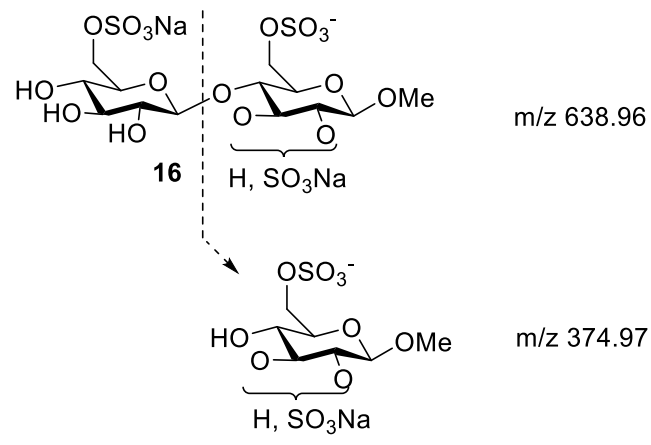

Scheme 5. MS/MS analysis of molecular ion of compound 16.

The sulfated molecules synthesized, together with some precursors or partially protected molecules that have been then tested for TLR4 interaction. 

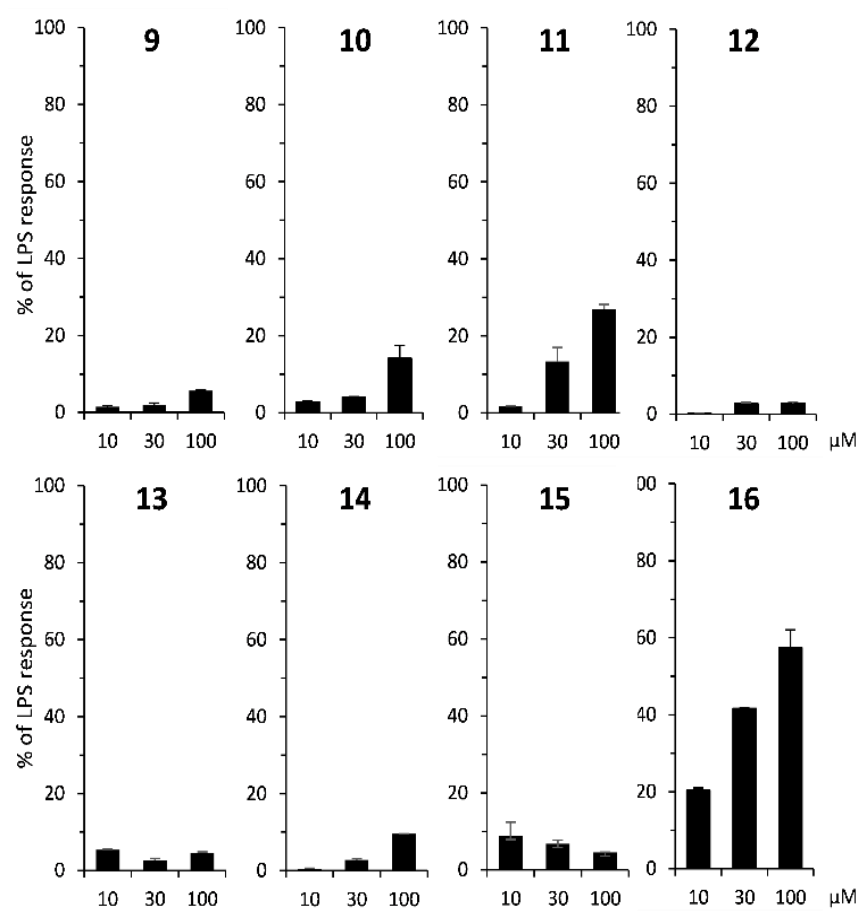

Figure 1. Stimulation of TLR4-expressing HEK cells by compounds 9 to 16. HEK-TLR4 cells were stimulated by the addition of compounds 9 to 16, each at the finale concentrations of 10, 30 and $100 \mu \mathrm{M}$. After $16 \mathrm{~h}$ of incubation, the production of SEAP related to the reporter gene activation was quantified by measuring the phosphatase activity released in cell-free supernatants with a chromogenic substrate $(620 \mathrm{~nm})$. Data of SEAP activity are means values \pm SEM from three separate

To test the capacity of compounds $\mathbf{9}$ to $\mathbf{1 6}$ to trigger signalization through TLR4, we decided to use a TLR4 transfected-cell line. A number of enzymatic bio-assays have been indeed developed, based on the use of stably TLR-transfected cell lines and designed to provide a sensitive method for the detection of TLR agonists. ${ }^{x \mathrm{~V}}$ Among them, HEK-Blue ${ }^{\mathrm{TM}} / \mathrm{hTLR} 4$ (HEK-TLR4) is a commercially available cell line, which is stably co-transfected to express the human TLR4 gene and a TLR-inducible reporter gene encoding a secreted embryonic alkaline phosphatase (SEAP). Parental HEK-293 cells do not express TLRs on their plasma membrane. Accordingly, TLR4 stimulation can be conveniently monitored through the release of SEAP from HEK-TLR4 cells by using a phosphatase detection assay. In addition, we used the HEK-Blue ${ }^{\mathrm{TM}} /$ Null1 (HEK-Null) cell line as a negative control. Indeed, this cell line is only transfected with the reporter gene encoding SEAP but is devoid of TLR4. Thus, the way by which compounds 9 to 16 induced the production of SEAP in HEK-TLR4 cells, but not in HEK-Null cells, is informative on their capacity to trigger signalization through TLR4. xxvi

First, we checked that compounds $\mathbf{9}$ to $\mathbf{1 6}$ did not induce any activation of HEK cells independently of TLR4 expression. To this end, HEK-Null cells were exposed to compounds $\mathbf{9}$ to $\mathbf{1 6}$ (each at 10, 30 and $100 \mu \mathrm{M}$ ) for $16 \mathrm{~h}$, after which time the activity of SEAP was measured. As expected, we found that these concentrations did not interfere with the production of SEAP from HEK cells that are devoid of TLR4.

Then, we tested the ability of HEK-TLR4 cells to detect the compounds $\mathbf{9}$ to $\mathbf{1 6}$ at the same finale concentrations (Figure 1). In our hands, non-sulfated molecules 9, 13 and 15 did not show any interaction with TLR4. Only the partially acetylated $\mathbf{1 0}$ showed a slight response at high concentration 
$(100 \mu \mathrm{M})$. Compound 11, bearing both acetate and sulfate esters induced a TLR4 response at $30 \mu \mathrm{M}$. Unexpectedly, the trisulfated (and non-acetylated) disaccharide 12 (obtained from 11) seemed inactive. Monosulfated Compound $\mathbf{1 4}$ showed a very low response, no significant difference was observed when compared with the non-substituted analog 15 . The highest response was shown by compound 16, the 3,6,6'-trisulfated disaccharide.

Clearly, these findings indicate that sulfate groups on the primary positions favored the interaction with the TLR4, thus triggering an inflammatory signalization. It is difficult however to explain the absence of activity of the trisulfated molecule 12, because the 6,6'-disulfation pattern of $\mathbf{1 6}$ is also present. Further investigations and other synthetic derivatives could allow to explain this result and the role of the specific position of sulfate groups for TLR4 binding. Anyway, our results on TLR4 binding make compound $\mathbf{1 6}$ a promising starting point for the regulation of the inflammatory response.

\section{Conclusions}

Altogether, we showed in this current work the potential of small oligosaccharides to modulate TLR4 activity, and we confirmed the need of sulfation and the key role of the 6-sulfate groups to trigger TLR4 signalization.

\section{Author Contributions}

S. T. and J. K. designed and supervised the synthetic work. R. N. performed the synthesis and the characterization of the compounds. F. A. designed the biological test performed by A. D. S. T., J. K. and F. A. wrote the paper and together with J. A. revised its final version.

\section{Conflicts of interest}

The authors declare no conflicts of interest.

\section{Acknowledgements}

The authors thank the Conseil Régional de Hauts-de-France (grant SOLIDE) for financial support and a PhD fellowship for R. N.

\section{Notes and references}

1 R. L. Modlin, H. D. Brightbill and P. J. Godowski, The Toll of Innate Immunity on Microbial Pathogens, N. Engl. J. Med., 1999, 340, 1834.

${ }^{2}$ T. Vasselon and P. A. Detmers, Toll receptors: a central element in innate immune responses, Infect. Immun., 2002, 70, 1033.

${ }^{3}$ D. M. Underhill and A. Ozinsky, Toll-like receptors: key mediators of microbe detection, Curr. Opin. Immunol., 2002, 14, 103.

4 M. Dajon, K. Iribarren and I. Cremer, Toll-like receptor stimulation in cancer: A pro- and anti-tumor double-edged sword, Immunobiology, 2017, 222, 89.

5 K. R. Michels, N. W. Lukacs and W. Fonseca, TLR Activation and Allergic Disease: Early Life Microbiome and Treatment, Curr. Allergy Asthma Rep., 2018, 18, 61.

6 S. Mukherjee, S. Karmakar and S. P. Babu, TLR2 and TLR4 mediated host immune responses in major infectious diseases: a review, Braz. J. Infect. Dis., 2016, 20, 193.

7 M. K. C. Brunialti, Milena, P. S. Martins, H. Barbosa de Carvalho, F. R. Machado, L. M. Barbosa, and R. Salomao, Shock, 2006, 25, 351.

8 E. Gülden and L. Wen, Toll-like receptor activation in immunity vs. tolerance in autoimmune diabetes, Front. Immunol., 24 March 2014. https://doi.org/10.3389/fimmu.2014.00119. 
${ }^{9}$ S. Gupta, A. Maratha, J. Siednienko, A. Natarajan, T. Gajanayake, S. Hoashi and S. Miggin, Analysis of inflammatory cytokine and TLR expression levels in Type 2 Diabetes with complications, Sci. Rep., 2017, 7, 7633.

$10 \mathrm{~S}$. Lehnardt, Innate immunity and neuroinflammation in the CNS: the role of microglia in Toll-like receptor-mediated neuronal injury, GLIA, 2010, 58, 253.

11 J. Ausseil, N. Desmaris, S. Bigou, R. Attali, S. Corbineau, S. Vitry, M. Parent, D. Cheillan, M. Fuller, I. Maire, M.-T. Vanier and J.-M. Heard, Early Neurodegeneration Progresses Independently of Microglial Activation by Heparan Sulfate in the Brain of Mucopolysaccharidosis IIIB Mice, PLoS One, 2008, 3, e2296.

12 F. Peri and V. Calabrese, Toll-like Receptor 4 (TLR4) Modulation by Synthetic and Natural Compounds: An Update, J. Med. Chem., 2014, 57, 3612.

13 J. Li, A. Csakai, J. Jin, F. Zhang and H. Yin , Therapeutic Developments Targeting Toll-like Receptor-4-Mediated Neuroinflammation, ChemMedChem, 2016, 11, 154.

${ }^{14}$ M. Molteni, A. Bosi and C. Rossetti, Natural Products with Toll-Like Receptor 4 Antagonist Activity, Int. J. Inflamm., 2018, Article ID 2859135

${ }^{15}$ F. A. Facchini, L. Zaffaroni, A. Minotti, S. Rapisarda, V. Calabrese, M. Forcella, P. Fusi, C. Airoldi, C. Ciaramelli, J.-M. Billod, A. B. Schromm, H. Braun, C. Palmer, R. Beyaert, F. Lapenta, R. Jerala, G. Pirianov, S. Martin-Santamaria and F. Peri, StructureActivity Relationship in Monosaccharide-Based Toll-Like Receptor 4 (TLR4) Antagonists, J. Med. Chem., 2018, 61, 2895.

${ }^{16}$ Y. Wang, S. Zhang, H. Li, H. Wang, T. Zhang, M. R. Hutchinson, H. Yin and X. Wang, Small-Molecule Modulators of Toll-like Receptors, Acc. Chem. Res., 2020, 53, 1046.

17 V. H. Pomin, Sulfated glycans in inflammation, Eur. J. Med. Chem., 2015, 92, 353.

${ }^{18}$ G. B. Johnson, G. J. Brunn, Y. Kodaira, and J. L. Platt, Receptor-mediated monitoring of tissue well-being via detection of soluble heparan sulfate by toll-like receptor 4, J. Immunol., 2002, 168, 5233.

${ }^{19}$ L. E. Collins, and L. Troeberg, Heparan sulfate as a regulator of inflammation and immunity, J. Leukoc. Biol., $2018,1$.

20 A. Borio, A. Holgado, J. A. Garate, R. Beyaert, H. Heine and A. Zamyatina, Disaccharide-BasedAnionic Amphiphiles as Potent Inhibitors of Lipopolysaccharide-Induced Inflammation ChemMedChem, 2018, 13, 2317.

21 V. Calabrese, R. Cighetti and F. Peri, Molecular simplification of lipid A structure: TLR4-modulating cationic and anionic amphiphiles, Mol. Immunol., 2015, 63, 153.

${ }^{22} \mathrm{~K}$. Larsen, C. E. Olsen and M. S. Motawia, A facile protocol for direct conversion of unprotected sugars into phenyl 4,6-Obenzylidene-per-O-acetylated-1,2-trans-thioglycosides, Carbohydr. Res., 2003, 338, 199.

${ }^{23}$ N. Basu, S. K. Maity, A. Chaudhury and R. Ghosh, Trichloroisocyanuric acid (TCCA): an efficient green reagent for activation of thioglycosides toward hydrolysis, Carbohydr. Res., 2013, 369, 10.

${ }^{24}$ H. Tanaka, Y. Nishiura and T. Takahashi, An Efficient Convergent Synthesis of GP1c Ganglioside Epitope, J. Am. Chem. Soc., 2008, 130, 17244.

xxv L.-Y. Huang, J. L. DuMontelle, M. Zolodz, A. Deora, N. M. Mozier and B. Golding, Use of Toll-Like Receptor Assays To Detect and Identify Microbial Contaminants in Biological Products, J. Clin. Microbiol., 2009, 47, 3427.

xxvi H. Hacine-Gherbi, A. Denys, M. Carpentier, A. Heysen, P. Duflot, P. Lanos and F. Allain, Use of Toll-like receptor assays for the detection of bacterial contaminations in icodextrin batches released for peritoneal dialysis, Toxicol. Rep., 2017, 4, 566. 